\begin{tabular}{|c|c|c|c|}
\hline \multirow{2}{*}{$\begin{array}{c}\text { LARUS } \\
\text { Hrvatska akademija } \\
\text { znanosti i umjetnosti }\end{array}$} & 52 & $21-34$ str. & Zagreb 2017 \\
\cline { 2 - 4 } & \multicolumn{3}{|c|}{$\begin{array}{c}\text { Primljeno 3 7. 2017. } \\
\text { Prihvaćeno na sjednici Razreda za prirodne znanosti HAZU 19.10.2017. }\end{array}$} \\
\hline
\end{tabular}

\title{
THE NEW BREEDING SITES OF SOME CONTINENTAL BIRD SPECIES IN THE COASTAL AREA OF THE SOUTHERN VELEBIT
}
Novi nalazi gniježđenja nekih kontinentalnih vrsta u obalnom području južnog Velebita

\author{
Gordan Lukač, Marijan Milovac, Nikica Bušljeta
}

Public Institution Paklenica National Park, dr. Franje Tuđmana 14a 23244 Starigrad-Paklenica, Croatia

\begin{abstract}
This paper specifies new breeding sites of seven continental bird species in the coastal area of the Southern Velebit, in Starigrad-Paklenica and Seline, about one kilometre south of the border of the Paklenica National Park. In addition to a distribution map for each species in the Paklenica National Park during the nesting season, the paper includes records of their nesting within the Park. The seven species are: the Great Spotted Woodpecker Dendrocopos major, the Robin Erithacus rubecula, the Spotted Flycatcher Muscicapa striata, the Blackcap Sy/via atricapilla, the Marsh Tit Parus palustris, the Crested Tit Lophophanes cristatus and the European Nuthatch Sitta europaea. For these species, the lowest altitudes of nesting have been specified, as well as breeding sites along the eastern Adriatic coast, known based on literary data.
\end{abstract}

Keywords: Southern Velebit, Great Spotted Woodpecker, Robin, Spotted Flycatcher, Blackcap, Marsh Tit, Crested Tit, European Nuthatch

\section{INTRODUCTION}

The diversity of the Velika Paklenica and Mala Paklenica canyons is evident in specific microclimate characteristics, temperature inversion, the movement of certain continental plant (such as European Hop Hornbeam Ostrya carpinifolia and

e-mail:sluzba-zastite@paklenica.hr 
Beech Fagus sylvatica) and bird species (Marsh Tit Parus palustris and Great Spotted Woodpecker Dendrocopos major) from higher altitudes areas within the National Park towards the coastal area (LukAč \& STIPČEvić 1997, Lukač 2004), as well as the expansion of Mediterranean species (such as the Common Fig Ficus carica, Holm Oak Quercus ilex, Blue Rock Thrush Monticola solitarius, Melodious Warbler Hippolais polyglotta and Subalpine Warbler Sylvia cantillans) to the mountainous areas at higher altitudes (SNow \& Perrins 1998, Lukač 2004, 2011). Data on the above can be found in the addendums of D. Rucner $(1965,1998)$ and R. Rucner $(1965)$. By observing the breeding birds, it has been noticed that certain continental species - occasionally and in certain years - nest in the coastal area. Therefore, it is worth recording both the successful nesting years and the overview of the general distribution of species in the Paklenica National Park. The following seven bird species were included in the short overview of species distribution: the Great Spotted Woodpecker, the Robin Erithacus rubecula, the Spotted Flycatcher Muscicapa striata, the Blackcap Sylvia atricapilla, the Marsh Tit, the Crested Tit Lophophanes cristatus and the European Nuthatch Sitta europaea. The distribution of those species is described as recorded over the 22-year period of research in the area during the nesting season, both in the central part of the Park and in the coastal area.

\section{MATERIAL AND METHODS}

The research was conducted in the coastal area of Starigrad-Paklenica and Seline in the period between April and June. Field research was conducted between 1996 and 2010 for the purpose of preparing a bird atlas, while the special-purpose field visits took place between 2011 and 2017. At the same time, birds were observed in the canyons of Velika Paklenica and Mala Paklenica, as well as in the coastal area. At the surveyed sites, researchers spent a total of 396 field days in the coastal area, i.e. 18 active field days over the 22-year period of research. The methodology of preparing the bird atlas of the National Park is described in the Appendix of LUKAČ (2011). Literature data on the presence of those species on the eastern Adriatic islands have also been used (Krpan, 1965, 1970, 1977, 1980, Igalffy, 1980, HubaleK, 1986, LuKač et al. 1986, KRALj 1997, Tutiš et al. 2013). Data on the specimens were gathered from the collection of the Institute for Ornithology of the Croatian Academy of Sciences and Arts, as well as from the collection of the Croatian Natural History Museum in Zagreb (Sušić et al. 1988, Grbac \& Kralj 2008).

\section{RESULTS AND DISCUSSION}

\section{The Great Spotted Woodpecker}

The Great Spotted Woodpecker is a resident breeding species in the coastal area of Istria and inland Croatia (Rucner 1998, Lukač \& Stelko 2016). In the coastal area of south Dalmatia, this species was recorded as a breeding bird only in silver 
poplar forests in the Neretva river delta (RUCNER 1998). It is distributed across the southern part of Velebit, mostly in beech forests, beech-black pine forests, black pine forests, and beech-fir forests on the northern slope of Velebit facing the region of Lika, as well as in hop-hornbeam forests with trees up to 60 years old near the Velika Paklenica and Mala Paklenica stream. On the southern slope of the Velebit mountain, the Great Spotted Woodpecker was observed at the altitude of 1,300 m a. s. 1., whereas on the northern slope, it was recorded at the altitude of 1,200 m a.s.1. at Bunovac. Nesting of the Great Spotted Woodpecker pair was recorded only once, in May 2003, in an old elm tree at a camping site in Starigrad-Paklenica. On this occasion, the pair successfully raised their young. The Great Spotted Woodpecker is a common species during the non-breeding season on the east Adriatic coast. The first specimens of this bird species can be seen as early as at the beginning of July, and they stay there until mid-April. In the period between 1996 and

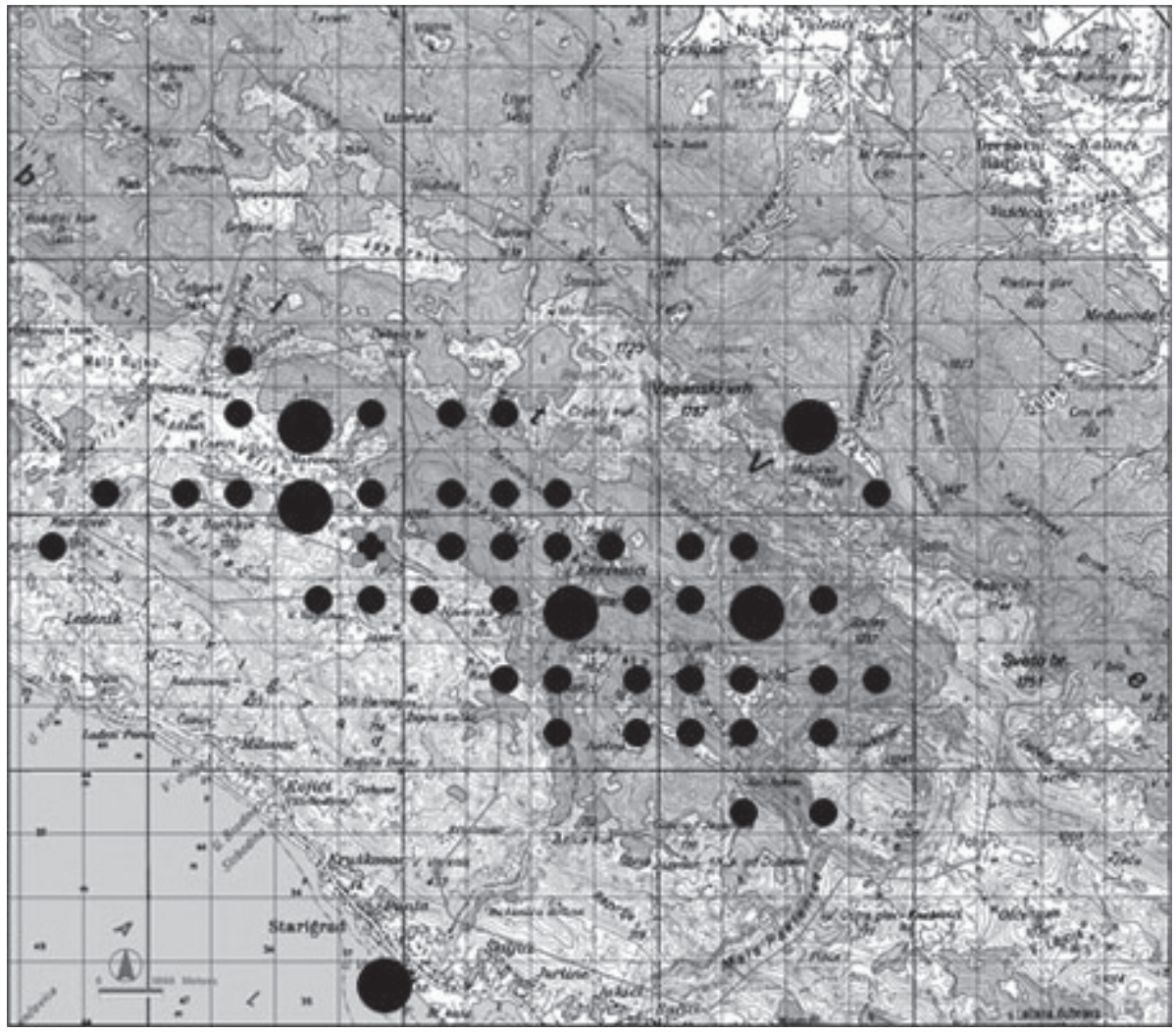

Figure 1. Distribution $\bullet$ of the Great Spotted Woodpecker in the Paklenica National Park during the nesting season and breeding quadrants.

Slika 1. Rasprostranjenost • velikog djetlića u doba gniježđenja u Nacionalnom parku Paklenica. kvadranti u kojima je zabilježeno gniježđenje. 
2009, 35 to 40 pairs of the species nested in the wider area of the Paklenica National Park. In the recent years, the population trend has slightly increased, amounting to 40-50 pairs. It is estimated that 15 to 30 specimens of this bird species spend the winter in the coastal area. In the Central Dalmatia, the Great Spotted Woodpecker was also spotted nesting in old trees in the area of the Skradinski Buk waterfall in the Krka National Park (LukAč et al. in print). All the known breeding records were from the inland area, with no breeding records from any island (RUCNER, R. 1965, Krpan 1970, 1977, 1980, Igalffy 1980, Hubalek 1986, Sušić et al. 1988, Kralj, 1997, Rucner, 1998, Snow \& Perrins 1998, Grbac \& Kralj 2008, Lukač et al. 2015).

\section{The Robin}

The Robin is a common breeding bird in the inner and certain coastal areas of Istria (RuCNer 1998, Lukač \& Stelko 2016). Owing to moist forest stands in

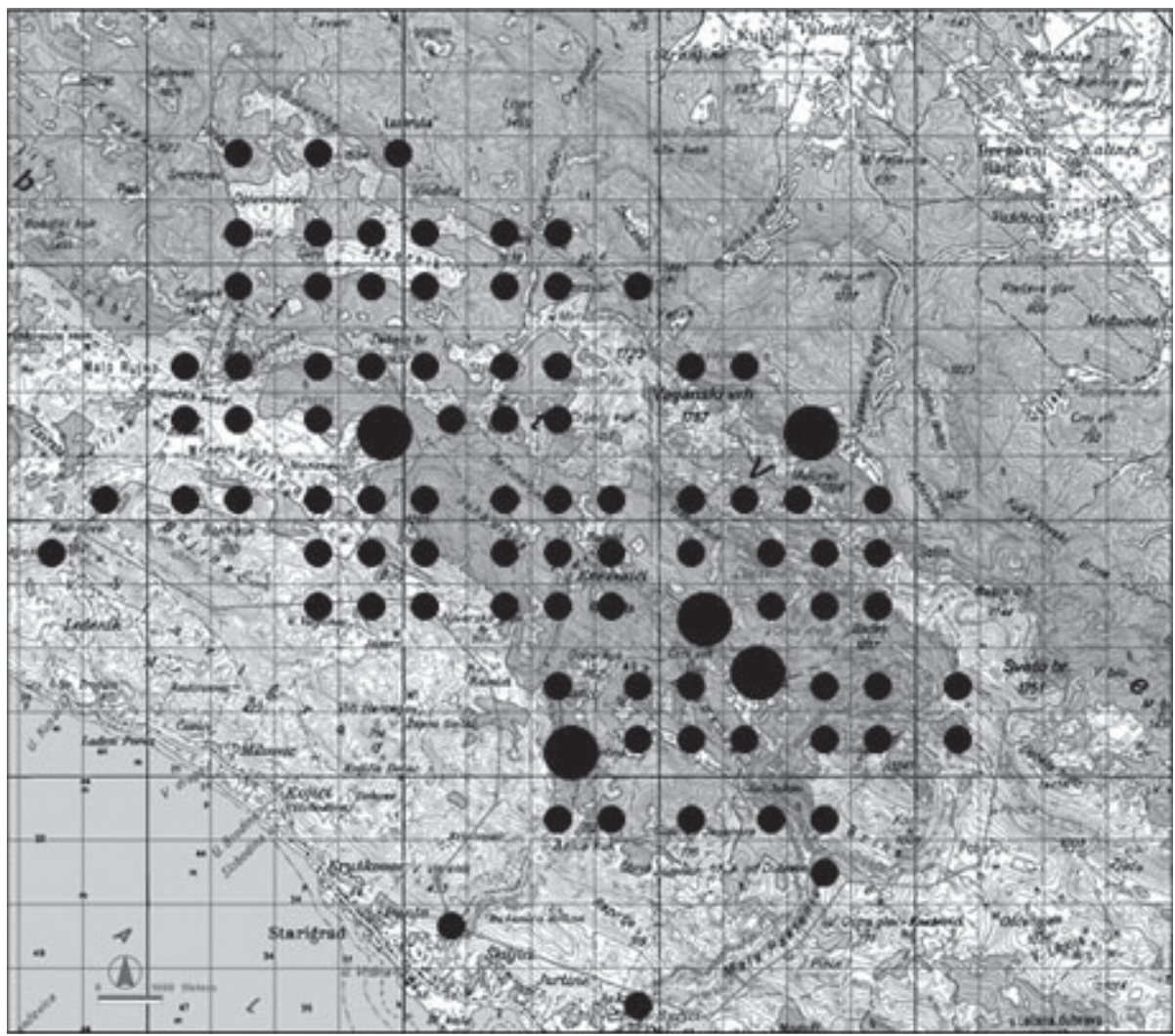

Figure 2. Distribution of the Robin in the Paklenica National Park during the nesting season - and breeding quadrants

Slika 2. Rasprostranjenost crvendaća u vrijeme gniježđenja •u Nacionalnom parku Paklenica i kvadranti gdje je utvrđeno gniježđenje 
Istria, its presence extends to Opatija and Lovran (KRALJ 1997, RuCNER 1998). In the Kvarner region, during the breeding season, this species stays in chestnut forests Castanea sativa and hop-hornbeam forests of the islands of Krk and Cres (Kralj 1997, Rucner 1998). As a genuine continental and montane species, it was recorded at altitudes of $250 \mathrm{~m}$ to 1,600 m a.s.l. on the Velebit mountain. In the Paklenica National Park, the Robin is one of the most common breeding bird species in the central forest stands. During 2001, 2002 and 2003, several Robin pairs were observed staying in the groves of Aleppo pine, at the exit of the Velika Paklenica and Mala Paklenica canyons. However, nesting has not been confirmed. It is most widely spread in beech forests and beech-black pine forests in the central part of the National Park. Additionally, it is commonly found in black pine forests. The Robin is a common wintering bird, recorded in the coastal area from late September or early October. During some winters, its numbers are high, and it stays until late March or early April. Until 2009, 350 to 400 pairs of the Robin had nested in the area of the National Park. The succession and overgrowing of vegetation between 2010 and 2017 resulted in a somewhat increased population, with the current number of approximately 1100 to 1200 Robin pairs.

\section{The Spotted Flycatcher}

The Spotted Flycatcher is recorded as the breeding bird of the coastal area of Istria, around Rovinj, and in Savudrija (Rucner 1998, Lukač \& Stelko 2016), as well as on the island of Krk and near Vinodol. Sightings were reported in the central part of Dalmatia, along the Čikola river. It has additionally been observed in the southern part of Dalmatia, on the Pelješac peninsula, and the islands of Mljet and Korčula (Rucner 1998, Snow \& Perrins 1998). The Spotted Flycatcher nests in the central part of the Paklenica National Park, whereas in the coastal area, it is most commonly found around the entrance to the Velika Paklenica and Mala Paklenica canyons. There is a record of its nesting along the very coastline of Starigrad, in the planted forest of Aleppo pine and black pine. In the southern part of the Velebit mountain, the Spotted Flycatcher nests in beech forests and beech-black pine stands in the central part of the National Park, at heights up to 1,000 metres. In May 1996, it was recorded to nest in the Velika Paklenica canyon, above the Lugarnica forest cottage. The Spotted Flycatcher built a nest in a crack in a rock wall, at the height of approximately $120 \mathrm{~cm}$, next to the hiking trail. A female Spotted Flycatcher was spotted in mid-May 2015 in a nest built on a beech tree at the Klimenta ridge (approximately $550 \mathrm{~m}$ a.s.1.). One pair of the Spotted Flycatcher with their young was spotted in May 2007 in the Aleppo pine forest in the Mala Paklenica canyon. In 2009, one pair of the Spotted Flycatcher built a nest in the Aleppo pine forest beneath the parking lot next to the Velika Paklenica stream, at an altitude of $100 \mathrm{~m}$ a.s.l. In 2014, one pair nested in the black pineAleppo pine forest next to the administrative building on the coast. A recently 
fledged bird was seen; it stayed there for a couple of days together with the adult birds. In early June 2017, a pair was recorded beneath the area of Anića Luka in the vicinity of water, where an adult bird fed a nestling in the hop-hornbeam forest. Around 60 to 70 pairs of the Spotted Flycatcher nest in the wider area of the National Park. The record dating from 2015, indicating that the Spotted Flycatcher nested on the shore of the Visovac Lake in the Krka National Park, proves that this species has gradually begun to inhabit sub-Mediterranean areas as well (LuKAČ et al. in print).

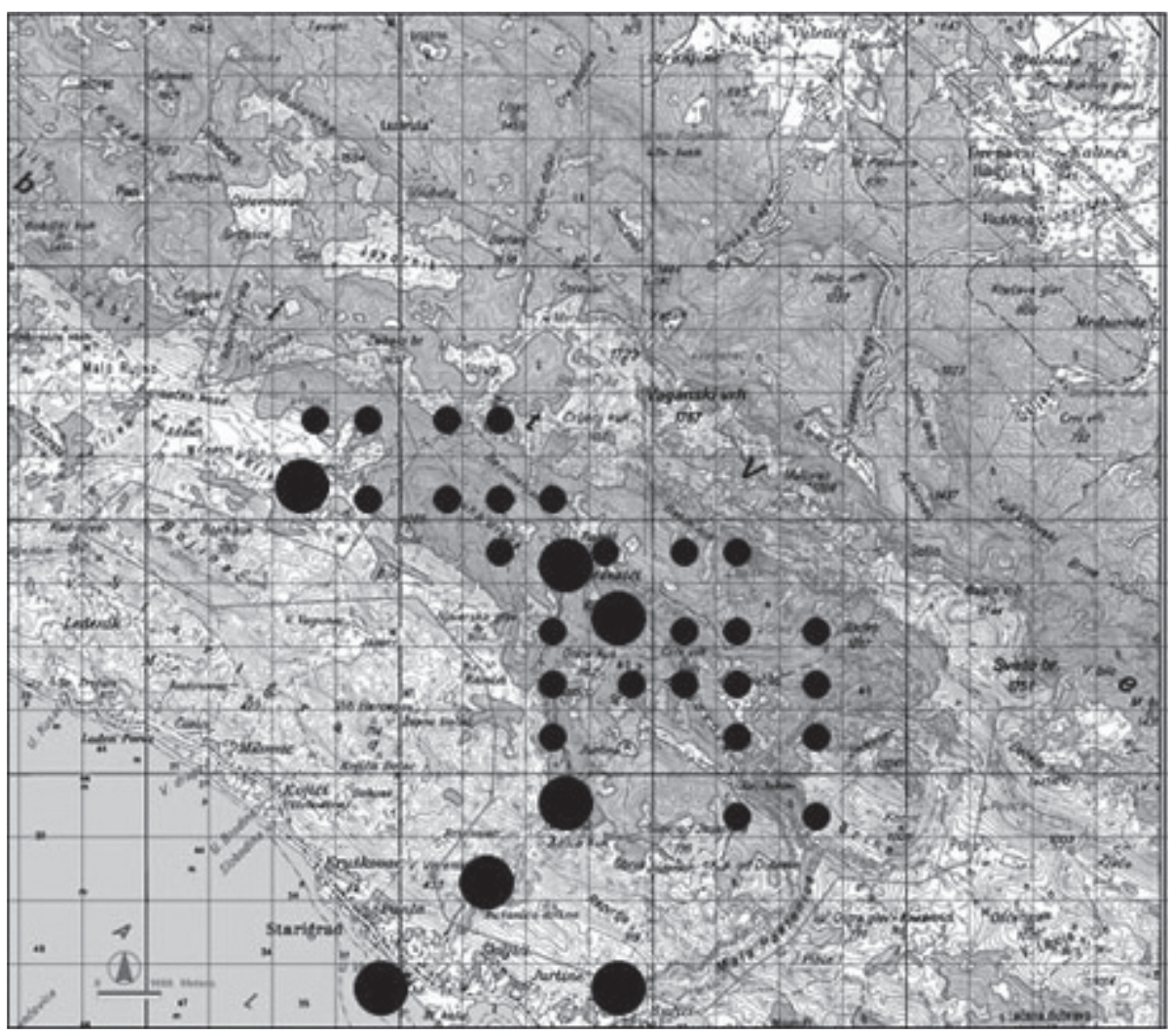

Figure 3. Nesting of the Spotted Flycatcher in the coastal area and inside the National Park. Distribution during breeding season in central part $\bullet$.

Slika 3. Gniježđenje sive muharice u obalnom dijelu i zadržavanje u vrijeme gniježđenja u središnjem dijelu parka

\section{The Blackcap}

The Blackcap is a common breeding bird across Istria (RuCNER 1998, LuKAČ \& STELKo 2016). In the coastal area, its presence was recorded in the Kvarner region 


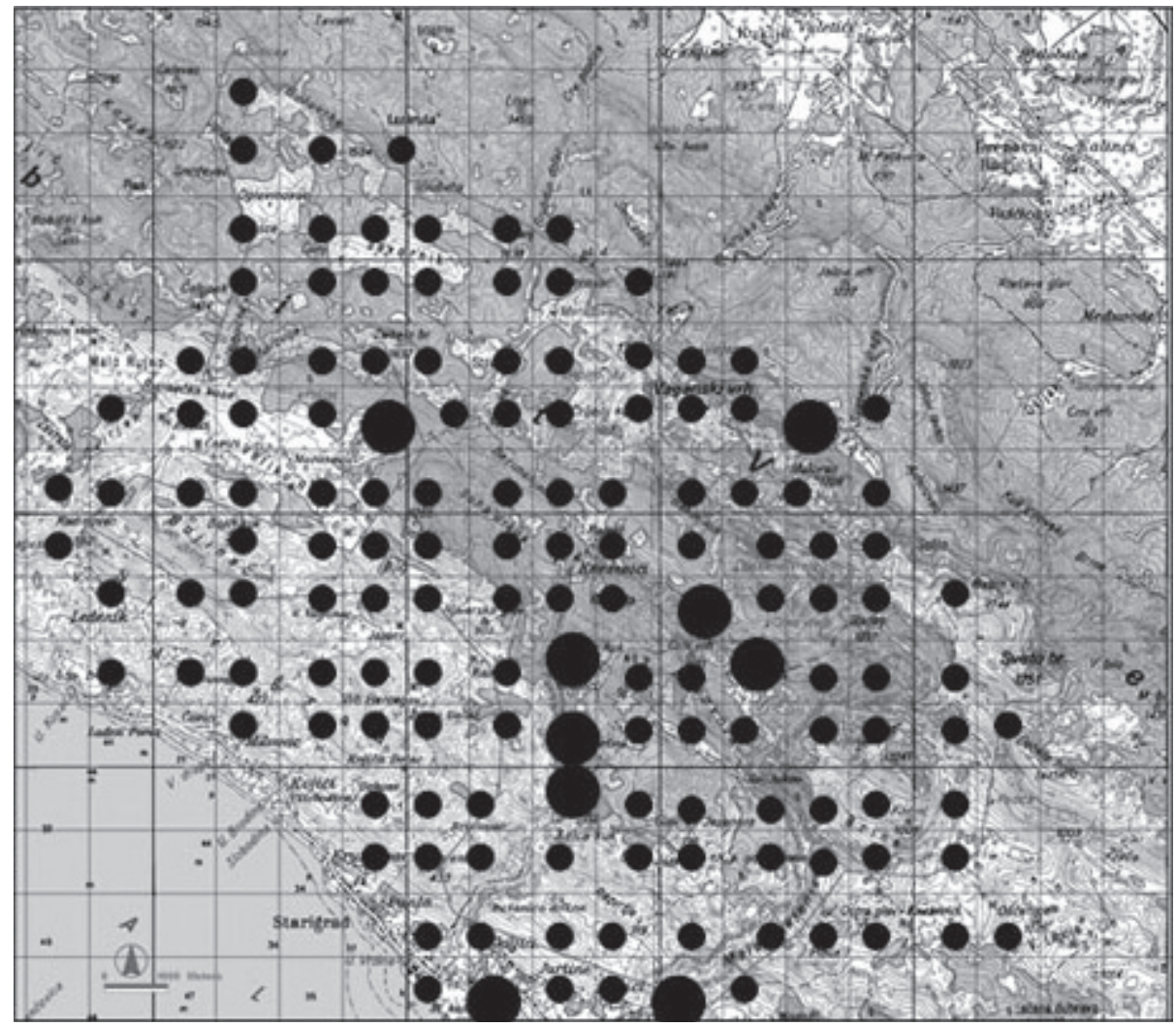

Figure 4. Distribution of the Blackcap in the Paklenica National Park $\bullet$ during the nesting season and quadrants with nest

Slika 4. Rasprostranjenost crnokape grmuše u vrijeme gniježđenja u Nacionalnom parku - Paklenica i kvadranti s pronađenim gnijezdima

and on the islands of Krk, Cres and Rab. It inhabits gorges covered with old forest stands and shrubs at Vratnik, Jablanac, all the way to the southern part of Velebit in the Velika Paklenica and Mala Paklenica canyons (RuCner 1998). In northern Dalmatia, it was observed beside the Zrmanja and Krka rivers. In central Dalmatia, it was spotted beside the Cetina river, whereas in southern Dalmatia, it was recorded in the area stretching as far as Konavle, as well as on the islands of Mljet, Korčula, Vis and Lastovo. The Blackcap was recorded in May 1985 as a bird nesting in Mala Paklenica at an altitude of $130 \mathrm{~m}$ a.s.l., and in the Velika Paklenica canyon at an altitude of $250 \mathrm{~m}$ a.s.l. Although the singing males are regularly sighted in the coastal area during the breeding season, nesting was not recorded until early June 2017, when a female was spotted with two fledglings. As a breeding bird in the wider area of the National Park, it was seen at altitudes ranging from $130 \mathrm{~m}$ to $1,700 \mathrm{~m}$. The Blackcap is one of the most common breed- 
ing species in black pine forests, beech forests and beech-black pine forests. It is regularly observed in the upper boundary of the mountain pine stands, where it is the third most numerous species, after the Dunnock Prunella modularis and the Common Linnet Carduelis cannabina. It has been recorded in almost all quadrants during the breeding season. However, even though the singing males stay in the coastal area, nesting has never been recorded with certainty. Despite a thorough search that lasted until 2017, no nest has ever been found and no young birds have been spotted in the coastal area. However, there were sightings of the singing males. The first finding of nesting was recorded at the beginning of June 2017, when an adult Blackcap was seen with two fledglings in Starigrad-Paklenica, about $300 \mathrm{~m}$ from the coast. Around 3,300 to 3,500 pairs inhabit the wider area of the National Park.

\section{The Marsh Tit}

The Marsh Tit is a common breeding bird in the hilly areas, whereas a smaller number of specimens has been recorded in the coastal area, at higher altitudes of Istria in inland areas; it was further spotted in the Brijuni National Park during winter (Rucner 1998, Lukač \& Stelko 2016). In addition, to this, during the breeding season, it was also spotted in the Kvarner region and on the slopes of the northern Velebit, beneath Vratnik and in Gornja Klada (Rucner 1998). In the wider area of the National Park, the Marsh Tit nests in the central forest stands. It was observed in beech forests, black pine forests and beech-black pine forests during the breeding season. It was recorded in beech-fir forests on the northern Velebit slope at an altitude of approximately $1200 \mathrm{~m}$ a.s.l. On the southern slope of Velebit, the Marsh Tit nests at altitudes of up to approximately 1,400 m a.s.l. In Velika Paklenica canyon, it was spotted several times at altitudes of 250 and $330 \mathrm{~m}$ a.s.l., while building a nest in a hop-hornbeam tree. There have been no records of nesting in the coastal area. In autumn, the first specimens of the Marsh Tit come to the coastal area as early as in August, staying there over the entire winter until mid-March. Around 50 to 70 pairs nest in the National Park. 


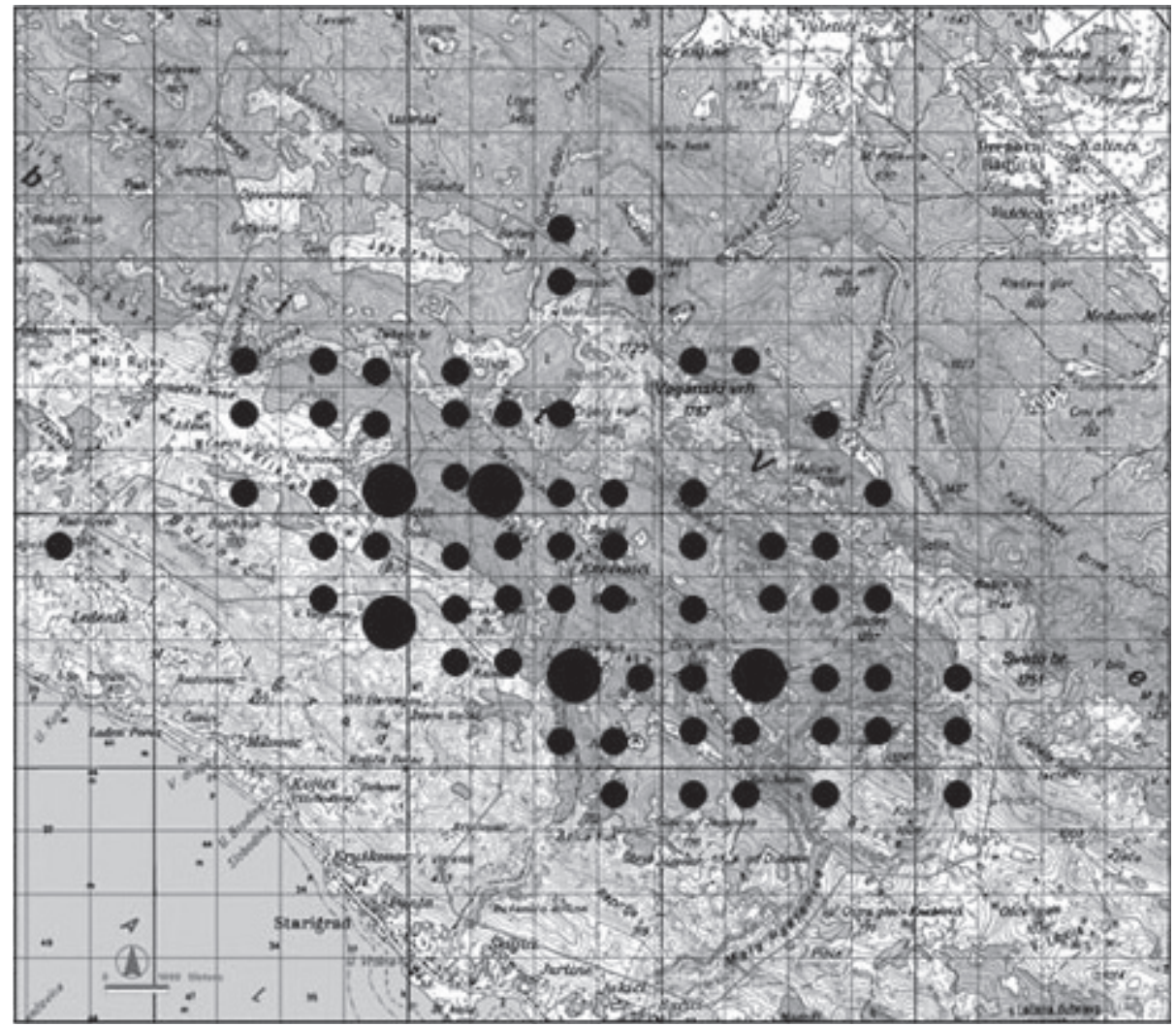

Figure 5. Distribution of the Marsh Tit in the wider area of the National Park during the nesting season $\bullet$ and locations of its nests in the national park

Slika 5. Rasprostranjenost crnoglave sjenice u vrijeme gniježđenja na širem području nacionalnog parka $\bullet i$ područja gdje je pronađeno gnijezdo.

\section{The Crested Tit}

The Crested Tit is distributed in black pine forests of the mountainous areas of Istria (Rucner 1998, Snow \& Perrins 1998, Lukač \& Stelko 2016). There was only one winter record, on 8 December 1972, in the coastal area of the Kvarner region, in the sub-Mediterranean vegetation of Vinodol (RUCNER 1998). In the Paklenica National Park, it was recorded in the central part of the Park, in black pine forests and mixed black pine-beech forests. In one quadrant, on the side facing the Lika region, it was observed in the beech-fir forest at Vaganac. The Crested Tit inhabits areas at altitudes ranging from 500 to 1,100 m a.s.l. In the wider area of the National Park, there were 31-40 breeding pairs until 2010, with a slight population increase trend resulting in the number reaching 70-80 pairs today. It is a true montane species, which has been observed during extremely 
harsh winters in the coastal areas since 2010. The first report on the nesting and feeding of young birds in the coastal area was made at the end of May 2015 on a camping side by the NP headquarters. That has been the only record of nesting in the coastal area so far.

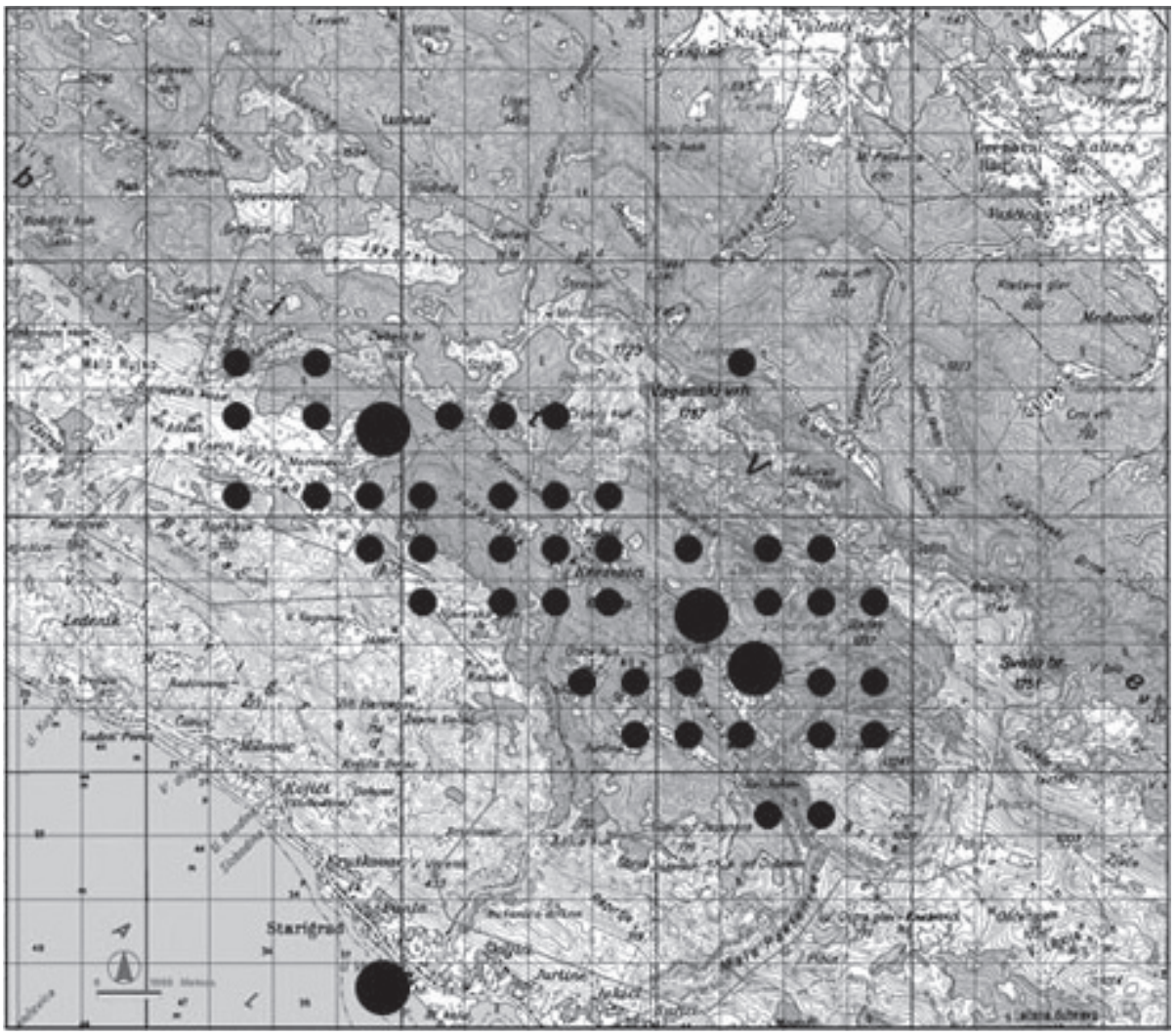

Figure 6. Distribution of the Crested Tit in the Paklenica National Park $\bullet$ during the nesting season and breeding quadrants $\mathbf{O}$.

Slika 6. Rasprostranjenost kukmaste sjenice u vrijeme gniježđenja • u Nacionalnom parku Paklenica i kvadranti gdje je zabilježeno gniježđenje 


\section{The European Nuthatch}

The European Nuthatch is distributed along the eastern coast of the Adriatic Sea at higher altitudes of the Dinaric Alps; so far, it has not been recorded nesting on the Adriatic islands. It is a common breeding bird in the forest areas of Istria at higher elevations, whereas its population in the coastal area is small and common in the Motovun Forest and the chestnut forests of Učka (RUCNER 1998, LukAč \& Sтецко 2016). In the coastal area of the Kvarner region, it is distributed in continental oases stretching as far as Vratnik (Rucner 1998). In the Paklenica National Park, it nests in all the older forest habitats. The nesting of the European Nuthatch was observed at altitudes from 300 to 1,600 m a.s.l. in hop-hornbeam forests, downy oak groves, beech forests, beech-black pine forests and black pine forests. It was also recorded in the zone of beech and fir trees at Bunovac. Owing to old stands of hop hornbeam and downy oak, and by using the canyon, it may descend to areas at altitudes as low as $250 \mathrm{~m}$ a.s.l., in the area of Anić Luka. A male European Nuthatch was spotted only once in April while building a nest in a downy oak tree in Jabukovac (Seline), at an altitude of approximately $15 \mathrm{~m}$ a.s.1., $800 \mathrm{~m}$ from the seashore. In the period from 1996 to 2009, there were around 100-120 pairs. In the period between 2010 and 2017, it was estimated that 500 to 600 pairs inhabited the National Park. The nesting of a European Nuthatch pair was recorded in June 1992, in an old European nettle tree Celtis australis in Senj; this is the second known record of nesting of this species in the immediate coastal area, on the southern slopes of Velebit. This species regularly nests in continental oases at higher altitudes (Vratnik, Gornja Klada, canyons of Velika Paklenica and Mala Paklenica), Rucner (1998). The European Nuthatch occasionally spends winters in the coastal area, and there are irregular records of its presence during certain winters, e.g. in 2000, 2008, 2015, from the end of June and also in November and December. In 2017, the first specimen of the European Nuthatch in the coastal areas was recorded as early as on 10 June. 


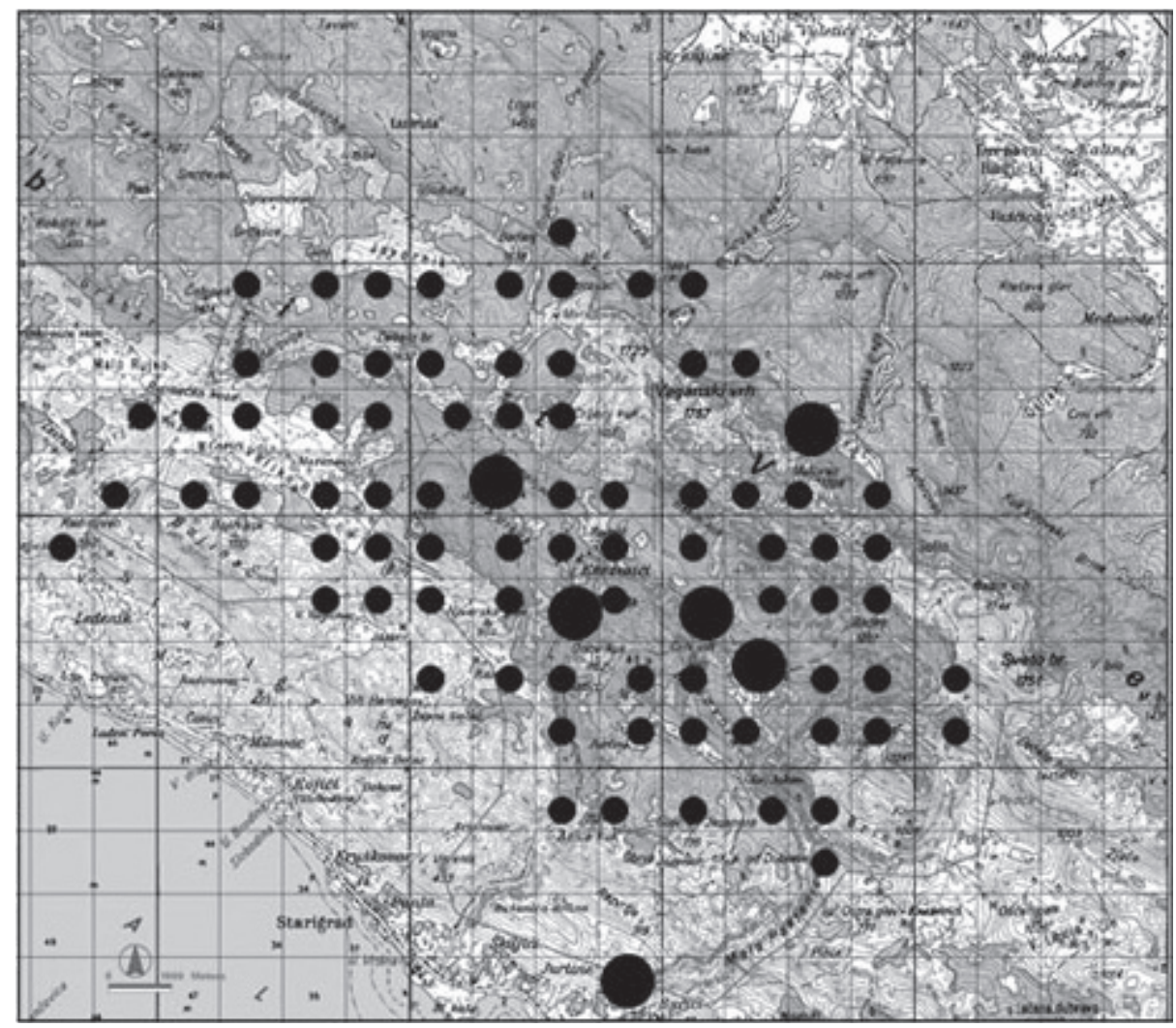

Figure 7. Distribution of the European Nuthatch in the Paklenica National Park during the nesting season $\bullet$ and breeding quadrants $\bigcirc$.

Slika 7. Rasprostranjenost brgljeza u vrijeme gniježđenja • u nacionalnom parku Paklenica. Kvadranti u kojima je zabilježeno gniježđenje

\section{Acknowledgements}

This paper is dedicated to the memory of our colleague Dragan Radović, Croatian ornithologist.

\section{References}

Grbac, I., Kralj, J. (2008): Katalog zbirke ptica Hrvatskog prirodoslovnog muzeja. Nat. Croat. 17, suppl. 1: 1-226.

Hubalek, Z. (1986): Avifauna of the Island of Brač. Larus 36-37: 167-173.

IgAlffy, K. (1980): Prilog poznavanju ptica otoka Paga. Larus 31-32: 55-89.

KralJ, J. (1997): Ornitofauna Hrvatske tijekom posljednjih dvjesto godina. Larus 46: 1-112. Krpan, M. (1965): Ptice otoka Visa i njemu blićih otočića. Larus 16-18: 106-150. 
KRPAN, M. (1970): Prilog poznavanju ornitofaune otoka Lastova. Larus 21-22: 65-83.

Krpan, M. (1977): Prilog ornitofauni otoka Korčule. Larus 29-30: 93-121.

KRPAN, M. (1980): Srednjodalmatinska ornitofauna. Larus 31-32: 97-156.

LuKAČ, G. (2004): Popis vrsta ptica šireg područja NP Paklenica“. Paklen. Zbor. 2, 105-112. Starigrad-Paklenica.

LukAČ, G. (2011): Atlas ptica Nacionalnog parka Paklenica. JU NP Paklenica \& HPM, Starigrad-Paklenica.

LuKAČ, G., STIPČEvić, M. (1997): Birds of National Park Paklenica. Nat. Croat. 6: 11-60.

Lukač, G., Stelko, R. (2016): Atlas ptica Istre. JU Natura Histrica, Pula.

Lukač, G., Tomić, D., Makjanić, I., Fišsrović, J. (1986): Prilog poznavanju ornitofaune srednjedalmatinskih otoka: kratki osvrt na ornitofaunu otoka Iža. Larus 36-37: 283-291.

Lukač, G., Vujčić-Karlo, S., Stani, W., Marguš, D. (in print): Ptice „Nacionalnog parka Krka“. Zbornik povodom 35. godišnjice NP Krka, Šibenik.

RUCNER, D. (1965): Značenje ornitofaune reliktnih borovih šuma Male Kapele i njen odnos spram ornitofauni ostalih šumskih zajednica ove vegetacijske zone. Larus 16-18: 38-78.

Rucner, D. (1998): Ptice hrvatske obale Jadrana. HPM i Ministarstvo razvitka i obnove, Zagreb.

Rucner, R.(1965): Odnos mediteranske vegetacije i mediteranskih elemenata ornitofaune na Balkanskom poluotoku. Larus 16-18, 79-105.

Snow, D.W., Perrins, C.M. (1998): The birds of the Western Palearctic. Concise Edition, Vol.1 \& 2 Nonpasserines and Passerines. Oxford University Press, Oxford New York.

Sušić, G., Radović, D., Bartovsky, V. (1988): Znanstvena zbirka ptičjih svlakova Zavoda za ornitologiju JAZU. pp 37-88 in Meštrov, M., Sušıć, G. (ed.) : Ornitologija u Hrvatskoj, Zagreb.

Tutiš, V., Kralj, J., Radović, D., Ćiković, D., Barišıć, S. (2013): Crvena knjiga ptica Hrvatske. Državni zavod za zaštitu prirode, Ministarstvo zaštite okoliša i prirode. Zagreb. 


\section{SAŽETAK}

U prilogu se navode nalazi gniježđenja sedam kontinentalnih vrsta čije je gniježđenje zabilježeno u obalnom dijelu Starigrada-Paklenice i Selina, uz samu granicu ili kilometar južnije, izvan granice nacionalnog parka Paklenica. Uz karte rasprostranjenosti u vrijeme gniježđenja i nalaze gniježđenja u nacionalnom parku Paklenica, navode se literaturni podaci i poznati nalazi gniježđenja u istočnom dijelu hrvatske obale Jadrana za sljedeće vrste: veliki djetlić Dendrocopos majo), crvendać Erithacus rubecula, siva muharica Muscicapa striata, crnokapa grmuša Sylvia atricapilla, crnoglava sjenica Poecile palustris, kukmasta sjenica Lophophanes cristatus i brgljez Sitta europaea. lako su navedene vrste redovite gnjezdarice u višim, kontinentalnim i brdskim dijelovima nacionalnog parka, navode se neredoviti, povremeni nalazi gniježđenja u obalnom području i na nižim nadmorskim visinama. Tako je veliki djetlić do sada samo jednom zabilježen na gniježđenju u obalnom području u svibnju 2003. Njegovo gniježđenje je još u obalnom dijelu istočnog Jadrana utvrđeno u delti Neretve. Redovito se zadržava uz obalu u vrijeme proljetne i jesenske skitnje te zimi, već od srpnja, pa do ožujka, kada se sreće i na našim otocima. Crvendać se gnijezdi u unutrašnjosti nacionalnog parka već od 250 m, a dva mužjaka su promatrana na izlazima kanjona Velike i Male Paklenice. Gniježđenje crvendaća za sada nije sa sigurnošću zabilježeno u obalnom području. Crnokapa grmuša je gnjezdarica viših dijelova: od 250 m u kanjonu Velike Paklenice, odnosno od $130 \mathrm{~m}$ u kanjonu Male Paklenice, pa do $1700 \mathrm{~m}$. U obalnom području je promatrana redovito u sezoni gniježđenja, no gniježđenje je potvrđeno u lipnju 2017. kada su promatrana dva mlada poletarca. Siva muharica je češća gnjezdarica unutrašnjih, središnjih dijelova nacionalnog parka, a njeno gniježđenje uz obalu je utvrđeno sa sigurnošću u svibnju i lipnju 2014. god. U 2015. god. je pronađeno gnijezdo i na jezeru Visovac u NP Krka. Crnoglava sjenica je na najnižim nadmorskim visinama gnijezdila od 250 do $330 \mathrm{~m} \mathrm{u}$ kanjonu Velike Paklenice. lako se u jesen u obalnom području zadržava već od kolovoza, pa do sredine ožujka, ljeti nije do sada gnijezdila u šumarcima alepskog i crnog bora u obalnom području. Kukmasta sjenica je promatrana na gniježđenju u svibnju 2015. u obalnom području. Glavnina rasprostranjenosti je u središnjem dijelu parka od 500-1100 m u miješanim šumama bukve i crnog bora, čistim šumama crnog bora i miješanim šumama bukve i jele. Brgljez je do sada najniže u nacionalnom parku zabilježen u kanjonu Velike Paklenice na 300 m. Gradnja gnijezda u travnju 2009. je zabilježena na lokalitetu Jabukovac (Seline) na nadmorskoj visini od $15 \mathrm{~m}$ i udaljenosti od $800 \mathrm{~m}$ od morske obale. U lipnju 1992. je promatran par na kopriviću u Senju uz cestu prema Vratniku, oko 500 m udaljen od morske obale i na nadmorskoj visini od oko $20 \mathrm{~m}$. Za sve naveden vrste se iznose literaturni podaci o poznatim nalazima gniježđenja uz istočnu hrvatsku obalu Jadrana. 